\title{
Bovine platelet aggregation by Fusobacterium necrophorum
}

\author{
M. KANOE and M. YAMANAKA
}

\section{Department of Veterinary Microbiology, Faculty of Agriculture, Yamaguchi University, Yamaguchi 753, Japan}

\begin{abstract}
Summary. Fusobacterium necrophorum aggregated bovine platelets. The aggregation was paralleled by the haemagglutinating ability of the organism. Treatment of the bacterial cells with antiserum to the homologous purified haemagglutinin reduced the degree of platelet aggregation. Scanning electronmicroscopy revealed that little lysis of the affected platelets occurred during the 1-h incubation period. Purified haemagglutinin became bound to the surfaces of the platelet cells as shown by immunofluorescence microscopy. These observations suggest that platelet aggregation is mediated by the haemagglutinin and may be related to the pathogenicity of the bacterium.
\end{abstract}

\section{Introduction}

The ability to induce platelet aggregation is associated with virulence in some micro-organisms which induce thrombocytopenia, disseminated intravascular coagulation, and other coagulative effects (Kurpiewski et al., 1983). Microbial components such as lipopolysaccharides (Morrison et al., 1978), tuberculin (Rourke et al., 1979), candida mannan (Maisch and Calderone, 1981), and peptidoglycan (Greenblatt et al., 1978) are known to contribute to platelet aggregation.

Fusobacterium necrophorum, a pathogen commonly found in animals, adheres to bovine ruminal epithelial cells (Kanoe and Iwaki, 1987). It is suspected that the bacterium sometimes penetrates into the venous system and then infects the visceral organs (Kanoe et al., 1984). A recent study (Forrester et al., 1985) revealed that bovine isolates of $F$. necrophorum could aggregate human platelets in platelet-rich plasma. Little information, however, is available about whether the bacterium causes aggregation of bovine platelets and what bacterial component is responsible for the bacterium-platelet interaction. In this paper, we report aggregation of bovine platelets by $F$. necrophorum and the role played by the bacterial haemagglutinin (HG).

\section{Materials and methods}

\section{Bacterial strains and culture}

$F$. necrophorum strains employed in this study were VPI $2891,118,130$, and 410 , kindly supplied by $\mathrm{Dr}$

Received 6 May 1988; revised version accepted 8 Sep. 1988.
Shinjo, Miyazaki University, Japan and S-45 from Dr Miwatani, Osaka University, Japan. As described previously (Nagai et al., 1984), the organisms were cultured at $37^{\circ} \mathrm{C}$ for $24 \mathrm{~h}$ in modified heart infusion broth supplemented with cysteine monohydrochloride $0.1 \%$ $\mathrm{w} / \mathrm{v}$ and ascorbic acid $0 \cdot 1 \% \mathrm{w} / \mathrm{v}$, collected by centrifugation at $8000 \mathrm{~g}$ for $20 \mathrm{~min}$, washed three times with phosphate-buffered saline (PBS, $\mathrm{pH} 7 \cdot 2$ ) and resuspended in PBS to a density of $10^{7}$ cells $/ \mathrm{ml}$.

\section{Platelets}

Bovine platelets were prepared by the method of Dausset et al. (1960). Nine volumes of heparinised bovine fresh blood were mixed with one volume of ethylenediaminetetraacetic acid disodium salt (EDTA) $5 \% \mathrm{w} / \mathrm{v}$. The mixture was centrifuged at $1000 \mathrm{~g}$ for $10 \mathrm{~min}$ at $4{ }^{\circ} \mathrm{C}$. The platelet-rich plasma was collected and centrifuged at $3000 \mathrm{~g}$ for $30 \mathrm{~min}$. The pellet was washed three times with a solution containing four volumes of $\mathrm{Na}_{2} \mathrm{HPO}_{4}$ $0.94 \% \mathrm{w} / \mathrm{v}$ in saline, one volume of $\mathrm{KH}_{2} \mathrm{PO}_{4} 0.9 \% \mathrm{w} / \mathrm{v}$ in saline, 20 volumes of saline and EDTA at a final concentration of $0.33 \% \mathrm{w} / \mathrm{v}$. The platelets were then resuspended in saline to a concentration of $10^{6} \mathrm{cells} / \mathrm{ml}$.

\section{Platelet aggregation}

The platelet suspension $(0.5 \mathrm{ml})$ and the bacterial suspension $(0.5 \mathrm{ml})$ were mixed in a siliconised tube and incubated at $37^{\circ} \mathrm{C}$ for $1 \mathrm{~h}$ in a water bath. One drop of the mixture was smeared over a glass slide, covered with a cover glass, and examined by phase contrast microscopy $(\times 600)$. Usually, three objective fields per slide were observed. Percentage aggregation was expressed as (number of aggregated platelets/total number of platelets) $\times 100$. 


\section{Haemagglutinin ( $H G)$ and $H G$ antiserum}

$F$. necrophorum HG was prepared according to the method of Nagai et al. (1984). Briefly, $5 \mathrm{ml}$ of the bacterial cell suspension $\left(10^{7}\right.$ cells $\left./ \mathrm{ml}\right)$ containing trypsin (Difco, Detroit) $0 \cdot 1 \% \mathrm{w} / \mathrm{v}$ was held at $37^{\circ} \mathrm{C}$ for $1 \mathrm{~h}$. The trypsin was removed by washing twice with a mixture of $0.15 \mathrm{M}$ $\mathrm{NaCl}$ and $10 \mathrm{~mm}$ Tris- $\mathrm{HCl}$ buffer at $\mathrm{pH} 7.0$ (TBS). The cells were resuspended in TBS supplemented with cysteine monohydrochloride $2 \% \mathrm{w} / \mathrm{v}$ and ascorbic acid $2 \% \mathrm{w} / \mathrm{v}$, incubated at $37^{\circ} \mathrm{C}$ for $1 \mathrm{~h}$, sonicated with a super-sonic vibrator (VR 150P, Tomy Seiko, Tokyo) and then centrifuged at $10000 \mathrm{~g}$ for $30 \mathrm{~min}$ at $4^{\circ} \mathrm{C}$. The supernate was filtered through a membrane filter (pore size, $0.6 \mu \mathrm{m}$ ) and purified by Sephadex G-100 (Pharmacia, Uppsala) column chromatography with TBS. Purity of the fraction was confirmed by polyacrylamide gel electrophoresis and agar gel double immunodiffusion tests. The HG preparation had a protein content of $140 \mu \mathrm{g} / \mathrm{ml}$. HG antiserum was prepared in rabbits by four intramuscular injections, at weekly intervals, of $1 \mathrm{ml}$ of a mixture containing the $\mathrm{HG}$ emulsified with an equal volume of Freund's complete adjuvant. Sera were collected one week after the last injection and stored at $-20^{\circ} \mathrm{C}$.

\section{Haemagglutination test}

As described previously (Nagai et al., 1984), the bacterial suspension $(50 \mu \mathrm{l})$ was diluted serially in doubling dilutions in the wells of a plastic microtitration tray. An equal volume of chicken red blood cell suspension, $1 \% \mathrm{v} / \mathrm{v}$, was added to each well. After incubation at $37^{\circ} \mathrm{C}$ for $30 \mathrm{~min}$ and room temperature for $1 \mathrm{~h}$, the test was read. Haemagglutination titre was estimated as the highest dilution that showed complete reaction.

\section{Inhibition of platelet aggregation}

Bacterial suspension $(0.8 \mathrm{ml})$ was mixed with $0.2 \mathrm{ml}$ of each of three dilutions of homologous HG antiserum (1 in 5,1 in 10 , and 1 in 50 in PBS), allowed to stand at $37^{\circ} \mathrm{C}$ for $1 \mathrm{~h}$ and then washed twice with PBS at $8000 \mathrm{~g}$ for 20 min. The bacterial cells were resuspended in PBS to a density of $10^{7}$ cells $/ \mathrm{ml}$. Subsequently the bacterial suspension was mixed with an equal volume of the platelet suspension and incubated at $37^{\circ} \mathrm{C}$ for $1 \mathrm{~h}$. One drop of the mixture was smeared over a glass slide and examined by phase contrast microscopy. Percentage inhibition was calculated from the following formula:

$$
\left[\begin{array}{l}
\text { Number of platelets aggregated by } \\
\text { antiserum-treated bacteria }- \text { control } \\
\begin{array}{l}
\text { Number of platelets aggregated by } \\
\text { untreated bacteria (control) }
\end{array}
\end{array}\right] \times 100
$$

\section{Immunofluorescence}

The platelet suspension $(0.5 \mathrm{ml})$ was mixed with the HG $(0.5 \mathrm{ml}$; protein content, $576 \mu \mathrm{g} / \mathrm{ml})$, left to stand at $37^{\circ} \mathrm{C}$ for $1 \mathrm{~h}$, washed twice with PBS, resuspended in a small volume of PBS, and then smeared on a glass slide. The smear was dried, fixed with acetone for $15 \mathrm{~min}$ and exposed to a 1 in 10 dilution of homologous $\mathrm{HG}$ antiserum at $37^{\circ} \mathrm{C}$ for $30 \mathrm{~min}$ in a moist chamber. After washing with PBS it was exposed to a 1 in 20 dilution of fluorescein isothiocyanate-conjugated goat antiserum to rabbit IgG at $37^{\circ} \mathrm{C}$ for $1 \mathrm{~h}$. After washing, the platelets were examined by fluorescence microscopy. As a control, PBS was employed instead of the HG.

\section{Scanning electronmicroscopy}

Bacterial suspension $\left(0.5 \mathrm{ml}, 10^{7}\right.$ cells $\left./ \mathrm{ml}\right)$ and platelet suspension $\left(0.5 \mathrm{ml}, 10^{6}\right.$ cells $\left./ \mathrm{ml}\right)$ were mixed and incubated at $37^{\circ} \mathrm{C}$ for $1 \mathrm{~h}$. One drop of the mixture was smeared on a glass slide, fixed in glutaraldehyde $2 \% \mathrm{w} / \mathrm{v}$ in $0.1 \mathrm{M}$ cacodylate buffer, $\mathrm{pH} 7 \cdot 2$, dehydrated for $10-\mathrm{min}$ intervals in a series of ethanol preparations $(50,70,80$, $90,95,99$ and $100 \%$ ), and dried by a critical point drying apparatus (JEOL IFC-1100, Japan Electron Optics, Tokyo). After a gold evaporation step, specimens were examined with a scanning electronmicroscope (JSM-25S III, Japan Electron Optics, Tokyo) at an operating voltage of $25 \mathrm{kV}$.

\section{Statistical analysis}

Statistical significance between means was estimated by Student's $t$-test.

\section{Results}

\section{Platelet aggregation and haemagglutination}

All the five strains of $F$. necrophorum aggregated bovine platelets and three of them possessed ability to agglutinate chicken red cells. The aggregation of platelets usually began within $10 \mathrm{~min}$ and required about 40-60 min to reach a maximum value. As shown in fig. 1a and table I, strain VPI 2891 had high platelet aggregating and high haemagglutinating activities and this strain was used in subsequent tests.

\section{Scanning electronmicroscopy}

$F$. necrophorum aggregated bovine platelets with little lysis (fig. 2a). No differences were observed between the cell surfaces of the aggregated platelets and those of the unaggregated cells (fig. 2b).

\section{Immunofluorescence}

Fluorescence specific for the HG was observed on the surface of bovine platelets exposed to a purified HG preparation (fig. 3a). Little fluores- 

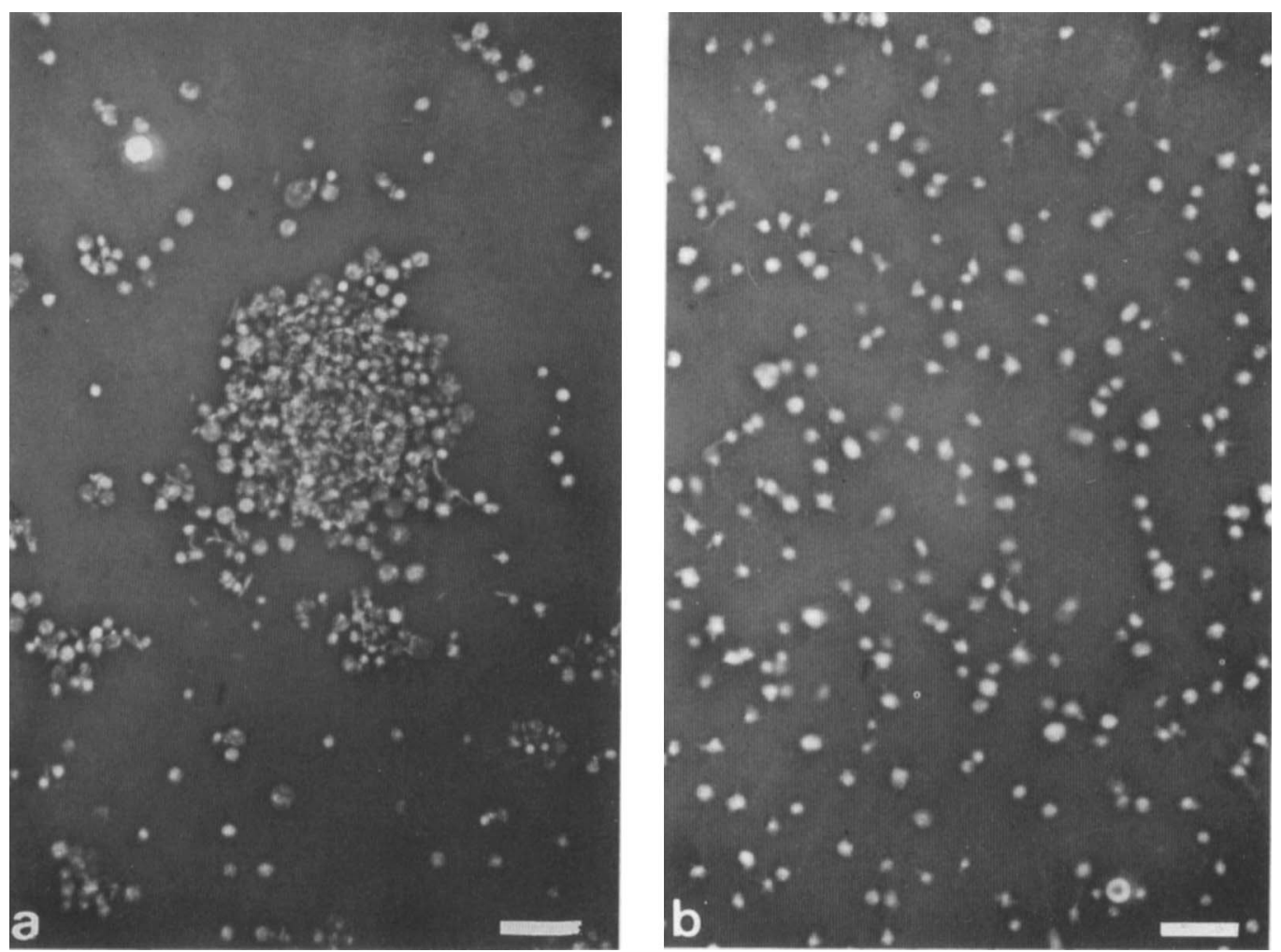

Fig. 1. Phase contrast micrographs of bovine platelets with (a) and without (b) F. necrophorum VPI 2891 . Bar $=10 \mu \mathrm{m}$.

cence was evident with control platelets, exposed to PBS alone and then treated with fluoresceinlabelled antiserum (fig. 3b).

\section{Aggregation inhibition}

Platelet aggregation by the $F$. necrophorum cell suspension was strongly inhibited by pretreatment of the bacteria with the homologous $\mathrm{HG}$ antiserum

Table I. Platelet aggregation and haemagglutinating ability of $F$. necrophorum strains

\begin{tabular}{lccc}
\hline $\begin{array}{l}\text { F. necrophorum } \\
\text { strain }\end{array}$ & Biovar & $\begin{array}{c}\text { Percentage } \\
\text { aggregation } \\
(\mathrm{SD})^{*}\end{array}$ & $\begin{array}{c}\text { Haemagglu- } \\
\text { tination } \\
\text { titre }\end{array}$ \\
\hline VPI 2891 & A & $73 \cdot 2(3 \cdot 0)$ & 128 \\
S-45 & B & $1 \cdot 0(0 \cdot 1) \dagger$ & 0 \\
410 & B & $7 \cdot 5(2 \cdot 4) \dagger$ & 0 \\
130 & B & $19 \cdot 1(2 \cdot 1) \dagger$ & 8 \\
118 & B & $20 \cdot 6(5 \cdot 5) \dagger$ & 8
\end{tabular}

* $\mathrm{SD}=$ standard deviation of triplicate determinations.

+ Significantly different $(\mathrm{p}<0.01)$ from the value for strain VPI 2891. in a dose-dependent manner. It was also inhibited slightly by normal rabbit serum, but the inhibitory effect was weaker than that of the HG antiserum (table II).

\section{Discussion}

Recently, attention has been paid to the pathogenic role of platelet aggregation by $F$. necrophorum in the establishment of human and animal necrobacillosis (Forrester et al., 1985). In this study we observed that bovine platelets were aggregated by $F$. necrophorum in vitro but aggregation was slightly slower than that reported for human platelets. It is well known that biovar A of the species demonstrates a high haemagglutinating ability with chicken red blood cells and is considered to be more virulent for laboratory animals, whereas biovar B shows little or no haemagglutinating ability and is thought to be less virulent (Langworth, 1977). Moreover, a recent study revealed that the $\mathrm{HG}$ of the biovar A strain (VPI 2891) mediates bacterial adherence to bovine ruminal epithelial cells (Kanoe and Iwaki, 1987). In this study, the biovar A strain (VPI 2891) showed strong platelet-aggregating 

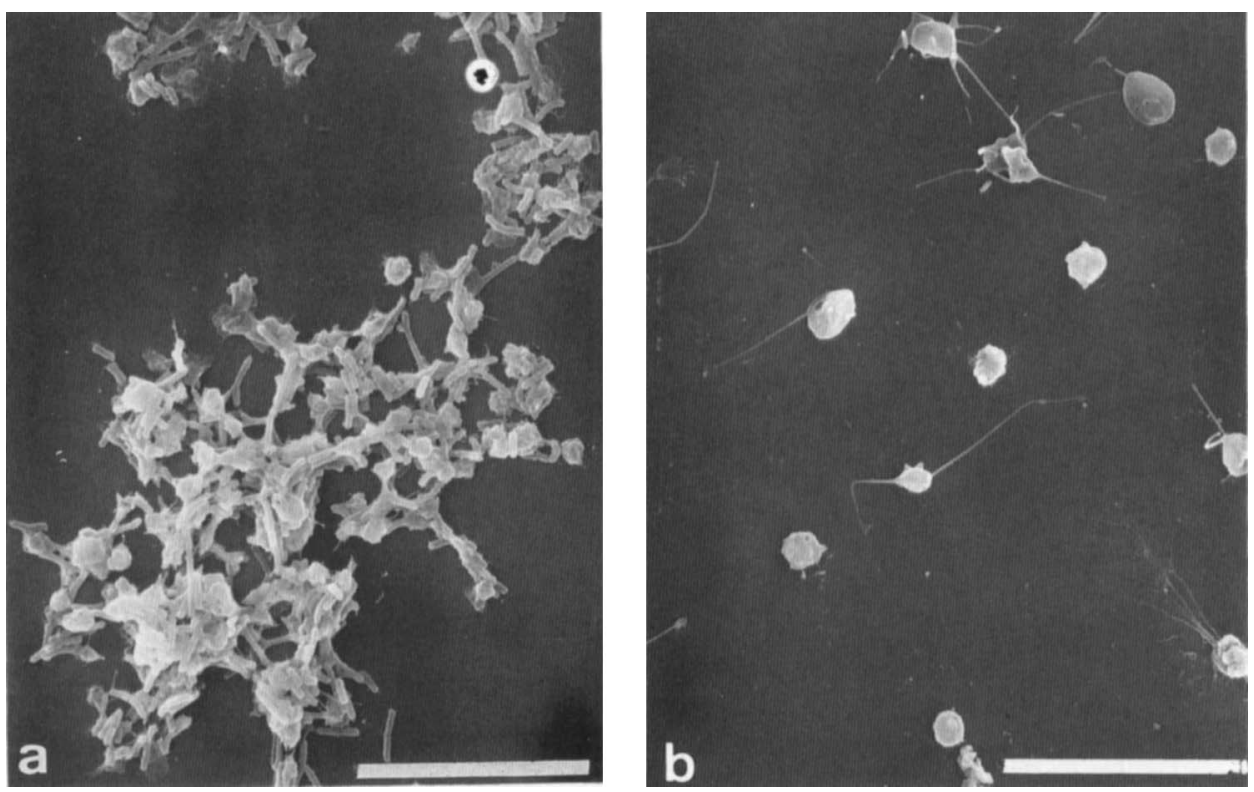

Fig. 2. Scanning electronmicrographs of bovine platelets with (a) and without (b) F. necrophorum VPI 2891. Bar $=10 \mu \mathrm{m}$.
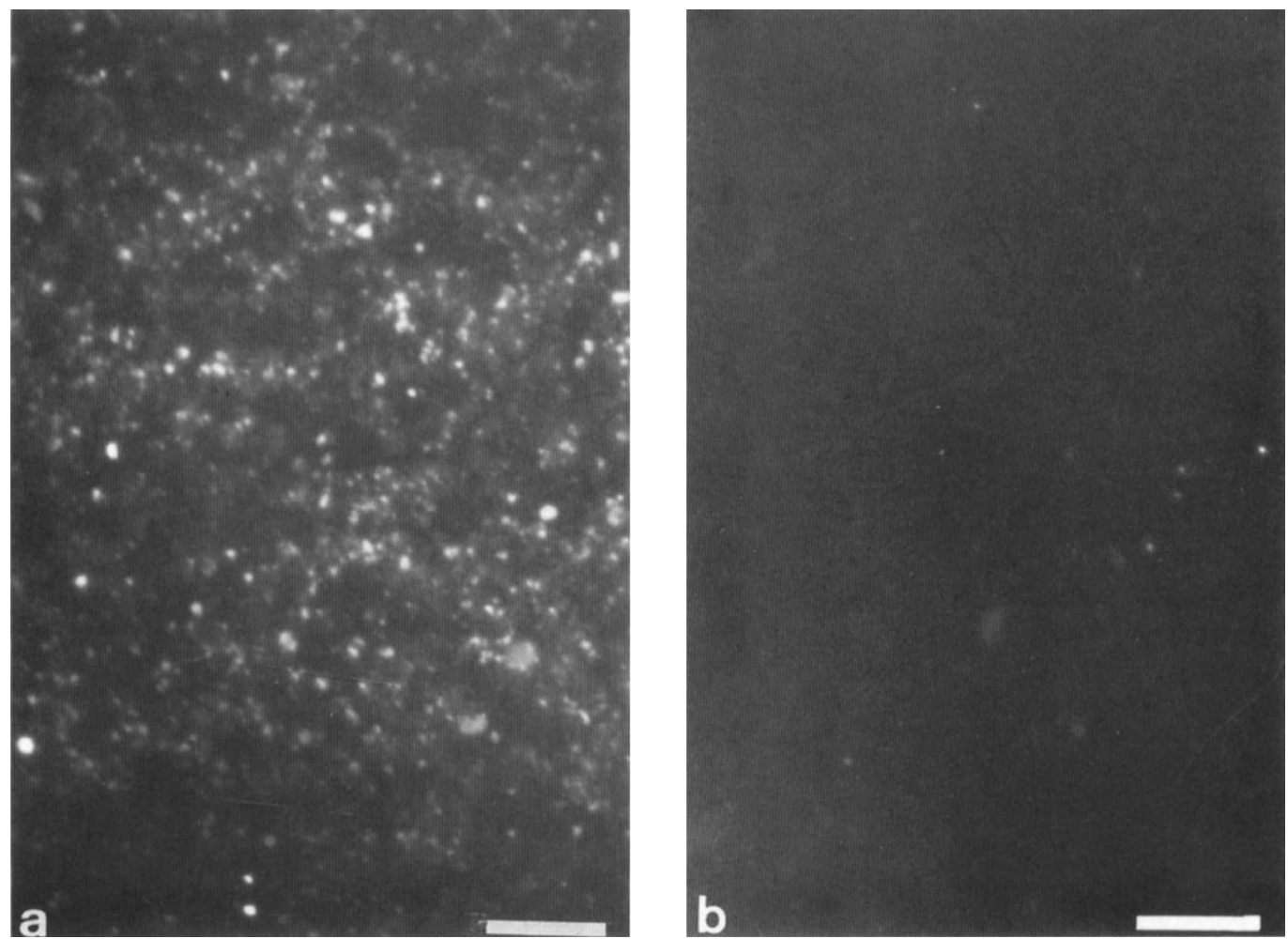

Fig. 3. Indirect immunofluorescence staining of bovine platelets treated with (a) the HG of $F$. necrophorum, and (b) PBS. $\mathrm{Bar}=20 \mu \mathrm{m}$. 
Table II. Inhibition of fusobacterial platelet aggregation by homologous haemagglutinin antiserum

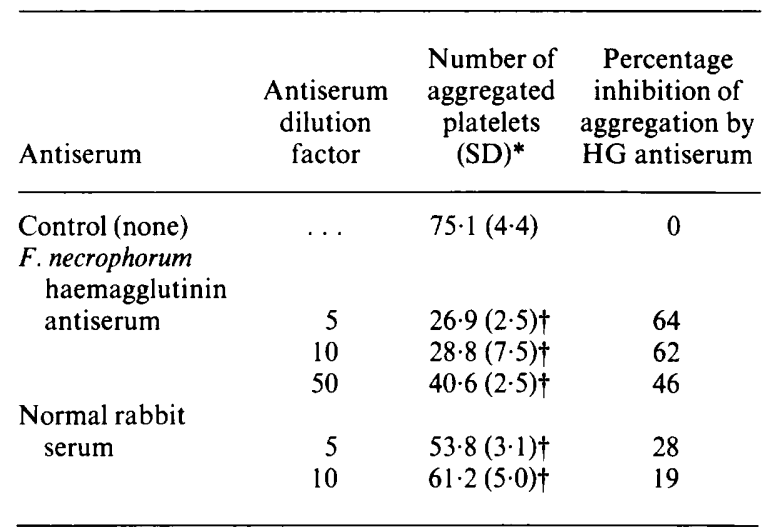

* SD, standard deviation of triplicate determinations.

$\uparrow$ Significantly different $(\mathrm{p}<0.01)$ from the control.

activity, whereas the other strains were less effective. These results suggest that $F$. necrophorum-

\section{REFERENCES}

Czuprynski C J, Balish E 1981 Interaction of rat platelets with Listeria monocytogenes. Infection and Immunity 33: 103-108.

Dausset J, Collin M, Colombani J 1960 Immune platelet isoantibodies. Vox Sanguinis 5: 4-31.

Forrester L J, Campbell B J, Berg J N, Barrett J T 1985 Aggregation of platelets by Fusobacterium necrophorum. Journal of Clinical Microbiology 22: 245-249.

Greenblatt J, Boackle J R, Schwab J H 1978 Activation of the alternate complement pathway by peptidoglycan from streptococcal cell wall. Infection and Immunity 19: 296-303.

Kanoe M, Iwaki K 1987 Adherence of Fusobacterium necrophorum to bovine ruminal cells. Journal of Medical Microbiology 23: $69-73$.

Kanoe M, Nouka K, Toda M 1984 Isolation of obligate anaerobic bacteria from bovine abscesses in sites other than the liver. Journal of Medical Microbiology 18: 365-369.

Kurpiewski G E, Forrester L J, Campbell B J, Barrett J T 1983 stimulated platelet aggregation may also be associated with the virulence of the strain.

Scanning electronmicroscopy revealed that platelet lysis did not occur. Platelet aggregation without lysis has also been observed with Listeria monocytogenes (Czuprynski and Balish, 1981) and Streptococcus pyogenes (Kurpiewski et al., 1983). Fusobacterial platelet aggregation was reduced when the bacteria were pretreated with the HG antiserum. Moreover, immunofluorescence studies demonstrated that the $\mathrm{HG}$ readily became bound to the platelet cell membranes. These observations suggest that bovine platelet aggregation by $F$. necrophorum is mediated by the bacterial HG.

It is thought that the bacteria colonise bovine ruminal epithelium, sometimes penetrating into the venous system and then infecting the abdominal tissues (Kanoe et al., 1984). The data presented here indicate that $F$. necrophorum-induced platelet aggregation could probably participate in the initial stage of the abscess formation during an infection with the bacterium.

Platelet aggregation by Streptococcus pyogenes. Infection and Immunity 39: 704-708.

Langworth B F 1977 Fusobacterium necrophorum: Its characteristics and role as an animal pathogen. Bacteriological Reviews 41 : 373-390.

Maisch P A, Calderone R A 1981 Role of surface mannan in the adherence of Candida albicans to fibrin-platelet clots formed in vitro. Infection and Immunity 32: 92-97.

Morrison D C, Kline L F, Oades Z G, Henson P M 1978 Mechanisms of lipopolysaccharide-initiated rabbit platelet responses: alternate complement pathway dependence of the lytic reaction. Infection and Immunity $20: 744-751$.

Nagai S, Kanoe M, Toda M 1984 Purification and partial characterization of Fusobacterium necrophorum hemagglutinin. Zentralblatt für Bakteriologie, Mikrobiologie und Hygiene A 258 : 232-241.

Rourke F J, Fan S S, Wilder M S 1979 Anticomplementary activity of tuberculin: relationship to platelet aggregation and lytic response. Infection and Immunity 23: 160-167. 